\title{
Patient satisfaction and experience with various modes of Xylocaine administration for cervical dilatation and endometrial curettage: a randomized interventional study
}

\author{
Swati Kanchan*, Shripad Hebbar
}

\begin{abstract}
Department of Obstetrics and Gynecology, Kasturba Medical College, Manipal Academy of Higher Education Manipal, Karnataka, India
\end{abstract}

Received: 05 January 2020

Accepted: 05 February 2020

\author{
*Correspondence: \\ Dr. Swati Kanchan, \\ E-mail: swati.kanchan89@gmail.com
}

Copyright: () the author(s), publisher and licensee Medip Academy. This is an open-access article distributed under the terms of the Creative Commons Attribution Non-Commercial License, which permits unrestricted non-commercial use, distribution, and reproduction in any medium, provided the original work is properly cited.

\begin{abstract}
Background: Patient satisfaction after a surgical procedure is an important outcome of hospital care. Many of the gynaecological menstrual problems such as abnormal uterine bleeding, postmenopausal bleeding requires endometrial evaluation which is done traditionally by dilatation and curettage. But this procedure is painful and requires appropriate pain management protocol. The aim is to evaluate the post-operative patient satisfaction following dilatation and curettage procedure.

Methods: This study was conducted in a tertiary care hospital belonging to a medical college. A total of 236 patients were recruited for the study who subsequently underwent dilatation and curettage with different mode of Xylocaine anesthesia for pain relief. Of them 16 patients were excluded due to valid reasons and the remaining 220 were interviewed face to face following the procedure. The level of anxiety was assessed using Beck's Anxiety inventory and also perception of satisfaction was documented along with complication related to the anesthesia.

Results: The overall level of satisfaction was higher in the group receiving both paracervical block and intrauterine instillation of lidocaine during the procedure of dilatation and curettage. A further analysis showed that increase in level of satisfaction was due to improvement in pain scores due to combined mode of paracervical and endometrial anesthesia.

Conclusions: A multimodal pain management protocol which involves pre-procedural sedation, combined cervical and endometrial anesthesia improves overall outcome with respect to reduction in anxiety scores and postoperative satisfaction levels.
\end{abstract}

Keywords: Dilatation and curettage, Patient satisfaction, Xylocaine

\section{INTRODUCTION}

The quality of a health care system has been clearly defined as the extent to which health care service increases the prospect of desired health outcome consistent with current professional acquaintance. Patient satisfaction is an imperative gauge of quality of care that can contribute to balance assessment of the structure, process and outcome of service. ${ }^{1-3}$
In late 1980's and early 1990's, the quality assurance movement in the field of health service sector gained quiet a momentum. ${ }^{4}$ The major aspect of this quality is patients experience was related to surgical and anaesthesia care. 1996 onwards, an editorial on patient's perspective towards satisfaction showed the emerging need for the assessment methodologies. ${ }^{5}$ Hence, patient's satisfaction has become and inseparable part of health care service. ${ }^{6,7}$ The measurement of patient's satisfaction 
is required to validate and measure health-care improvement in general. ${ }^{8}$ However at present there is no accurate and sensitive tool established for assessment of patient satisfaction due to the confounding factors as socioeconomic standard, demographic data, cultural level and cognitive ability of the patients. ${ }^{9}$ Small survey like this is associated with responder bias and cannot be used to judge or compare the health care service but can be used by professionals to improvise the level of care. ${ }^{10}$

In this modern era of increasing awareness, the value of patient satisfaction is the key to quality of health care. The aim of the present study is to evaluate the post procedural patient satisfaction following dilatation and curettage at KMC, Manipal.

\section{METHODS}

This study was conducted in a tertiary care hospital belonging to Kasturba Medical College, Manipal for a period of 2 years (Aug 2016 to July 2018). Prior to enrollment, ethical committee clearance was obtained from the hospital ethics committee (IEC 482/2016). A written consent was obtained from all women who were participating in the study.

\section{Inclusion criteria}

- All women with AUB scheduled for dilation and curettage

- Women who need endometrial curettage prior to surgery

- Subjects who gave consent for the procedure under local anesthesia

- $\quad$ Age of the subjects $>18$ years.

\section{Exclusion criteria}

- Women allergic to lidocaine

- Profuse uterine bleeding

- $\quad$ Profuse white discharge
- Impaired liver functions

- Significant cardiac or respiratory impairment

- Unable to understand VAS (visual analogue scale of $10)$.

Among 236 recruited subjects, (12 subjects refused to participate and 4 subjects had history of drug allergy) 220 underwent dilatation and curettage. All the patient received IM sedation with tramadol (50 mg IM) and vagolytic atropine injection $(0.6 \mathrm{mg} \mathrm{IM})$. The procedure was done only above-mentioned sedation in 40 patients and this group acted as control. 70 subjects were recruited for Xylocaine intrauterine instillation and 70 subjects were recruited for paracervical block. 40 received both the paracervical and Xylocaine intrauterine instillation. Sample size was more than adequate to arrive at statistically significant conclusions. Patient characteristics like age, parity was noted, pre-procedural anxiety related to the procedure was documented using Beck's Anxiety inventory (BAI). Post-operative satisfaction was assessed after 30 minutes of the procedure on a nominal scale (not satisfied, somewhat satisfied, satisfied, very much satisfied). Other prospective post procedure complications like nausea vomiting, abdominal pain, shivering, dizziness was also recorded.

\section{Statistical analysis}

It was done using statistical package for Social Sciences 16.0 (SPSS Inc. Chicago, Illinois, USA). A p value of < 0.05 was considered statistically significant. All statistical tests for significance of differences were done at a level of $5 \%$ using two-tailed t-test.

\section{RESULTS}

Table 1 shows demographic variables of all 220 participants of different local anaesthesia for dilatation and curettage. It can be noted that these demographic parameters were matched in all the four groups.

Table 1: Distribution of demographic variables (age, BMI, uterine length and endometrial thickness) in four groups.

\begin{tabular}{|ll|lll|l|}
\hline Groups & $\begin{array}{l}\text { No Xylocaine } \\
(\mathbf{N}=\mathbf{4 0}) \\
\text { Mean } \pm \text { SD }\end{array}$ & $\begin{array}{l}\text { Intrauterine } \\
\text { Xylocaine }(\mathbf{N}=70) \\
\text { Mean } \pm \text { SD }\end{array}$ & $\begin{array}{l}\text { Paracervical } \\
\text { block }(\mathbf{N}=70) \\
\text { Mean } \pm \text { SD }\end{array}$ & $\begin{array}{l}\text { Combined } \\
\text { route }(\mathbf{N}=40) \\
\text { Mean } \pm \text { SD }\end{array}$ & p value* \\
\hline Age & $48.6 \pm 10.6$ & $44.5 \pm 8.0$ & $46.6 \pm 7.5$ & $47 \pm 9.4$ & 0.109 \\
\hline BMI & $27.5 \pm 3.6$ & $26.9 \pm 4.6$ & $27 \pm 4.5$ & $28.2 \pm 4.2$ & 0.467 \\
\hline Uterine length & $7.3 \pm 1.7$ & $7.1 \pm 1.5$ & $7.3 \pm 1.4$ & $7.9 \pm 1.7$ & 0.064 \\
\hline Endometrial thickness & $12.6 \pm 6.9$ & $12.1 \pm 5.6$ & $12.9 \pm 5.5$ & $12.7 \pm 7.6$ & 0.895 \\
\hline
\end{tabular}

* One-way anova. Not significant.

All of the patients responded to Beck's Anxiety inventory and were categorized as mild, moderate and severe levels of anxiety and the results are shown in Table 2.
Table 2 demonstrates that there was no clinically significant difference in the level of anxiety (measured using Beck's Anxiety inventory (BAI).) between the 
groups as the $\mathrm{p}$ value of 0.27 are not significant among four groups of subjects underwent dilatation and curettage. This indicated that the above level of anxiety was found to be matched in all groups, suggesting that this was not a confounding variable. Studies have shown that higher anxiety leads to higher pain score and higher level of dissatisfaction.

Table 3 demonstrates the level of satisfaction among the subjects in all four group with $\mathrm{p}$ value obtained being significant $<0.05$. Subjects had higher satisfaction in combined group and least in no Xylocaine group.
Authors further analysed whether the improvement in the level of satisfaction was due to differences in the pain intensities felt during the procedure. The level of pain was assessed at four different points (cervical traction, cervical dilation, endometrial curettage and pain after 30 minutes of completion of procedure) and were summed up to represent total pain score.

Total pain score $=$ sum of VAS values of pain dues to cervical traction, cervical dilation, endometrial curettage and pain after 30 minutes of completion of procedure.

Table 2: Level of anxiety in four groups.

\begin{tabular}{|c|c|c|c|c|c|}
\hline Groups/ Anxiety & $\begin{array}{l}\text { No Xylocaine } \\
(\mathbf{N}=\mathbf{4 0}) \\
\mathbf{n}(\%)\end{array}$ & $\begin{array}{l}\text { Intrauterine } \\
\text { Xylocaine } \\
(\mathbf{N}=70) \text { n }(\%)\end{array}$ & $\begin{array}{l}\text { Paracervical } \\
\text { block }(\mathbf{N}=\mathbf{7 0}) \\
\text { n }(\%)\end{array}$ & $\begin{array}{l}\text { Combined route } \\
(\mathbf{N}=40) \\
\text { n }(\%)\end{array}$ & p value* \\
\hline & $20(50)$ & $23(32.9)$ & $22(31.4)$ & $19(47.5)$ & \multirow{3}{*}{0.27} \\
\hline & $12(30)$ & $32(45.7)$ & $30(42.9)$ & $11(27.5)$ & \\
\hline & $8(20)$ & $15(21.4)$ & $18(25.7)$ & $10(25)$ & \\
\hline
\end{tabular}

*Chi Square test, Pearson Chi-Square: 7.5, df: 6, Not significant, *Chi Square test, p value $<0.05$ is significant.

Table 3: Level of satisfaction in four groups.

\begin{tabular}{|c|c|c|c|c|c|}
\hline Groups/ Level of satisfaction & $\begin{array}{l}\text { No Xylocaine } \\
(\mathbf{N}=\mathbf{4 0}) \\
\mathrm{n}(\%)\end{array}$ & $\begin{array}{l}\text { Intrauterine } \\
\text { Xylocaine } \\
(\mathbf{N}=70) \mathbf{n}(\%)\end{array}$ & $\begin{array}{l}\text { Paracervical } \\
\text { block }(\mathbf{N}=\mathbf{7 0}) \\
\text { n }(\%)\end{array}$ & $\begin{array}{l}\text { Combined route } \\
(\mathbf{N}=40) \\
\mathrm{n}(\%)\end{array}$ & p value* \\
\hline Not satisfied & $15(37.5)$ & $21(30.0)$ & $13(18.6)$ & $3(7.5)$ & \multirow{4}{*}{$<0.05$} \\
\hline Somewhat satisfied & $13(32.5)$ & $19(27.1)$ & $17(24.3)$ & $9(22.5)$ & \\
\hline Satisfied & $7(17.5)$ & $16(22.9)$ & $19(27.1)$ & $11(27.5)$ & \\
\hline Very much satisfied & $5(12.5)$ & $14(20.0)$ & $21(30.0)$ & $17(42.5)$ & \\
\hline
\end{tabular}

*Chi Square test, Pearson Chi-Square: 20.2, df-9, Significant, *Chi Square test, p value $<0.05$ is significant.

Table 4: Total pain scores in all four groups.

\begin{tabular}{|llllll|}
\hline $\begin{array}{l}\text { Groups/ Total } \\
\text { pain scores }\end{array}$ & $\begin{array}{l}\text { No } \\
\text { Xylocaine }(\mathbf{N}=40) \\
\text { Mean } \pm \text { SD }\end{array}$ & $\begin{array}{l}\text { Intrauterine } \\
\text { Xylocaine }(\mathbf{N}=70) \\
\text { Mean } \pm \text { SD }\end{array}$ & $\begin{array}{l}\text { Paracervical } \\
\text { Block }(\mathbf{N}=70)\end{array}$ & $\begin{array}{l}\text { Combined } \\
\text { route }(\mathbf{N}=40)\end{array}$ & p value* \\
Mean \pm SD & Mean \pm SD & \\
\hline Total value & $17.65 \pm 2.1$ & $13.91 \pm 2.38$ & $13.21 \pm 2.33$ & $9.55 \pm 2.34$ & $<0.001$ \\
\hline
\end{tabular}

* One-way anova, df:3, F: 83.2, Significant, *One-way anova test, $\mathrm{p}$ value $<0.05$ is significant.

Table 5: Distribution of adverse effect in four groups.

\begin{tabular}{|lllll|}
\hline $\begin{array}{l}\text { Groups/ Adverse } \\
\text { effects }\end{array}$ & $\begin{array}{l}\text { No Xylocaine } \\
(\mathbf{N}=\mathbf{4 0}) \text { Mean } \pm \mathbf{S}\end{array}$ & $\begin{array}{l}\text { Intrauterine } \\
\text { Xylocaine }(\mathbf{N}=70) \\
\text { Mean } \pm \text { SD }\end{array}$ & $\begin{array}{l}\text { Paracervical } \\
\text { block }(\mathbf{N}=70) \\
\text { Mean } \pm \text { SD }\end{array}$ & $\begin{array}{l}\text { Combined } \\
\text { route }(\mathbf{N}=40) \\
\text { Mean } \pm \text { SD }\end{array}$ \\
\hline Total value & $17.65 \pm 2.1$ & $13.91 \pm 2.38$ & $13.21 \pm 2.33$ & $9.55 \pm 2.34$ \\
\hline No adverse effects & $25(62.5)$ & $54(77.1)$ & $47(67.1)$ & $25(62.5)$ \\
\hline Abdominal cramping & $3(7.5)$ & $4(5.7)$ & $2(2.9)$ & $1(2.5)$ \\
\hline Dizziness & $2(5)$ & $1(1.4)$ & $3(4.3)$ & $4(10)$ \\
\hline Nausea & $0(0)$ & $1(1.4)$ & $3(4.3)$ & $0(0)$ \\
\hline Shivering & $4(10)$ & $7(10)$ & $9(12.9)$ & $5(12.5)$ \\
\hline Shoulder pain & $1(2.5)$ & $1(1.4)$ & $1(1.4)$ & $2(5)$ \\
\hline Sweating & $3(7.5)$ & $1(1.4)$ & $2(2.9)$ & $1(2.5)$ \\
\hline Vasovagal symptoms & $2(5)$ & $1(1.4)$ & $1(1.4)$ & $1(2.5)$ \\
\hline Vomiting & $0(0)$ & $0(0)$ & $2(2.9)$ & $1(2.5)$ \\
\hline
\end{tabular}

* Chi Square test, Pearson Chi-square: 21.8, df:24, Not significant, *Chi Square test p value $<0.05$ is significant. 
It was found that combined group had least pain score as they received both paracervical block and intrauterine Xylocaine instillation. This may be probable reason why this group had better level of satisfaction compared to other groups.

Table 5 demonstrates the adverse effect noted in all four groups, maximum in combined group due to amount of drug followed by paracervical group, intrauterine Xylocaine and no Xylocaine group with non-significant statistical $\mathrm{p}$ value 0.59 .

However, it was important to note that no serious lifethreatening complication observed in any of the groups and all were managed conservatively at the time of occurrence of the event. Hence Xylocaine can be considered as a relatively safe drug.

Table 6: Level of satisfaction following intrauterine procedure in various studies.

\begin{tabular}{|c|c|c|c|c|c|c|c|c|}
\hline Study & Procedure & $\begin{array}{l}\text { Patients } \\
\text { (n) }\end{array}$ & $\begin{array}{l}\text { Intrauterine } \\
\text { medication, } \\
\text { dose }\end{array}$ & Comparator & $\begin{array}{l}\text { Reduced } \\
\text { pain? }\end{array}$ & $\begin{array}{l}\text { Pain } \\
\text { difference }\end{array}$ & $\begin{array}{l}\text { Study } \\
\text { quality }\end{array}$ & Comments \\
\hline $\begin{array}{l}\text { Present } \\
\text { study }\end{array}$ & $\begin{array}{l}\text { Dilatation } \\
\text { and } \\
\text { Curettage }\end{array}$ & 220 & $\begin{array}{l}2 \% \\
\text { Xylocaine } \\
5 \mathrm{~mL}\end{array}$ & $\begin{array}{l}\text { No xylocaine } \\
\text { Paracervical } \\
\text { block ( } 2 \% \\
\text { Xylocaine } \\
10 \mathrm{~mL})\end{array}$ & Yes & $\begin{array}{l}30 \% \text { more } \\
\text { comfortable } \\
\text { (direct } \\
\text { questioning) }\end{array}$ & Excellent & $\begin{array}{l}\text { Significant level of } \\
\text { satisfaction } \\
\text { obtained among the } \\
\text { patient in combined } \\
\text { group. }\end{array}$ \\
\hline $\begin{array}{l}\text { Vadhera } \\
\text { A, et } \\
\mathrm{al}^{11}\end{array}$ & $\begin{array}{l}\text { Surgical } \\
\text { evacuation }\end{array}$ & 119 & $\begin{array}{l}10 \mathrm{ml} \text { of } \\
\text { Xylocaine } \\
2 \%\end{array}$ & $\begin{array}{l}\text { Inj Midazolam } \\
0.04 \mathrm{mg} / \mathrm{Kg} \\
\text { body weight } \\
\text { and Inj. } \\
\text { Fentanyl } 0.002 \\
\text { mg/Kg for } \\
\text { conscious } \\
\text { sedation }\end{array}$ & Yes & $\begin{array}{l}21.84 \% \\
\text { comfortable } \\
\text { (direct } \\
\text { questioning) }\end{array}$ & Good & $\begin{array}{l}\text { Paracervical block } \\
\text { with conscious } \\
\text { sedation is an } \\
\text { effective and safe } \\
\text { method for surgical } \\
\text { evacuation of early } \\
\text { pregnancy. }\end{array}$ \\
\hline $\begin{array}{l}\text { Edelman } \\
\mathrm{A} \text {, et } \\
\mathrm{al}^{12}\end{array}$ & $\begin{array}{l}\text { Surgical } \\
\text { abortion }\end{array}$ & 80 & $\begin{array}{l}\text { 5-mL 4\% } \\
\text { Xylocaine }\end{array}$ & Saline & Yes & $\begin{array}{l}5 \% \text { more } \\
\text { satisfied } \\
\text { (direct } \\
\text { questioning) }\end{array}$ & Excellent & $\begin{array}{l}\text { Compared with } \\
\text { paracervical block } \\
\text { alone, the addition } \\
\text { of a } 4 \% \text { intrauterine } \\
\text { xylocaine infusion } \\
\text { resulted in a 5\% } \\
\text { pain relief. }\end{array}$ \\
\hline $\begin{array}{l}\text { Wong et } \\
\mathrm{al}^{13}\end{array}$ & $\begin{array}{l}\text { Suction } \\
\text { evacuation }\end{array}$ & 100 & $\begin{array}{l}10 \mathrm{ml} \text { of } 1 \% \\
\text { Xylocaine } \\
\text { With } 2 \mathrm{mg} \\
\text { Midazolam } \\
\text { and } 25 \mathrm{mg} \\
\text { fentanyl }\end{array}$ & Saline & Yes & $\begin{array}{l}18 \% \text { more } \\
\text { satisfied } \\
\text { (direct } \\
\text { questioning) }\end{array}$ & Good & $\begin{array}{l}\text { The patients } \\
\text { receiving conscious } \\
\text { sedation along with } \\
\text { paracervical block } \\
\text { had better pain } \\
\text { relief }\end{array}$ \\
\hline
\end{tabular}

\section{DISCUSSION}

We found higher level of satisfaction with higher level of anesthetic drug used in combined group receiving both paracervical block and intrauterine Xylocaine instillation during the procedure of dilatation and curettage. The outcome was not influenced by preexisting demographic parameters and pre-procedural level of anxiety, but directly related the level of pain perception during the procedure of dilatation and curettage.

Table 6 compares the outcome of present study with previous studies done relation to various uterine and cervical manipulations such as suction evacuation, surgical abortions. Vadhera A et al, studied 119 subjects undergoing suction evacuation in 2017 and stated approx. $25 \%$ patients were comfortable, for $65 \%$ patients the technique was acceptable, for about $18 \%$ of patients technique was tolerable and about $2.5 \%$ of patients was unacceptable immediately following the surgery, after 24 hours after the procedure $4.2 \%$ of patients told that the technique was unacceptable though there percentage is quite less.

The study concluded the use of conscious sedation in conjugation of paracervical block gives $21.84 \%$ higher level of satisfaction among the subjects, compared to $30 \%$ increased level of satisfaction as in the present study. ${ }^{11}$

Edelman in 2006 compared paracervical and paracervical in combination with $1 \%$ Xylocaine infusion intrauterine found no much pain relief during 1 st trimester abortion. ${ }^{12}$ Wong in 2002 studied subjects receiving conscious 
sedation along with paracervical block concluded to have better pain relief. ${ }^{13}$

Alshehri AA et al, we surveyed 353 patients in the first 24 hours after anesthesia, the major subjective outcome measure was patient satisfaction, also measured other predetermined outcomes, such as nausea, vomiting, pain and complications. The overall level of satisfaction was high 336 (95.2\%), with pain control and post op adverse effect were the confounding factor. ${ }^{14}$ They did not categorize the type of surgery the patients underwent.

Alsaif A et al, surveyed 303 patients stated that patient's satisfaction is the balance between prior expectations, and later, perceptions of the health care. They showed a great contribution of type of anesthesia in the degree of patients' satisfaction with both general and epidural/spinal anesthesia. They concluded survey found a moderate overall satisfaction of patients $(56.5 \%)$ and postoperative symptoms' control (pain nausea and vomiting) plays a great role in patients' satisfaction. ${ }^{15}$

This is a large study conducted at a tertiary care center in a developing country, with matching the confounding factor and adverse effect, considered different mode of anesthesia used for pain management for patient's satisfaction during dilatation and curettage and found the higher amount of Xylocaine was associated with higher patient satisfaction.

\section{Funding: No funding sources}

Conflict of interest: None declared

Ethical approval: The study was approved by the Institutional Ethics Committee

\section{REFERENCES}

1. Myles PS, Williams DL, Hendrata M, Anderson H, Weeks AM. Patient satisfaction after anesthesia and surgery: results of a prospective survey of 10,811 patients. Br J Anaesth. 2000;84:6-10.

2. Gill TM, Feinstein AR. A critical appraisal of the quality of quality-of-life measurements. JAMA. 1994;272:619-26.

3. Westbrook JI. Patient satisfaction: methodological issues and research findings. Aust Health Rev. 1993; $16: 75-88$

4. Eagle CJ, Davies JM. Current models of "quality" an introduction for anesthetists. Canadian $\mathrm{J}$ Anaesth. 1993;40(9):851-62.
5. Marcus BS, Greifenstein FE. The emotional responses of patients to surgery and anesthesia. Anesthesiol J Am Society Anesthesiol. 1960;21(5):502-7.

6. Fung D, Cohen MM. Measuring patient satisfaction with anesthesia care: a review of current methodology. Anesth Analg. 1998;87(5):1089-98.

7. Bell DM, Halliburton JR, Preston JC. An evaluation of anesthesia patient satisfaction instruments. AANA J. 2004;72:211-7.

8. Moonesinghe SR, Tomlinson AA. Quality improvement and revalidation: two goals, same strategy?. $\mathrm{Br} \mathrm{J}$ Anaesth. 2011;106(4):447-450.

9. Heidegger T, Saal D, Nuebling M. Patient satisfaction with anaesthesia care: what is patient satisfaction, how should it be measured, and what is the evidence for assuring high patient satisfaction? Best Pract Res Clin Anaesthesiol. 2006;20(2):331-46.

10. 1liffe S, Wilcock J, Manthorpe J, Moriarty J, Cornes M, Clough R, et al. Older people researching social issues (OPRSI). Can clinicians benefit from patient satisfaction surveys? Evaluating the NSF for Older People, 2005-2006. J Royal Society Med. 2008;101(12):598-604.

11. Vadhera A, Sharma SK, Dey M. The efficacy and safety of paracervical block with conscious sedation in surgical evacuation of early pregnancy. Inter J Biomed Adv Res. 2017;8(7);279-83.

12. Edelman A, Nichols MD, Leclair C, Jensen JT. Four percent intrauterine lidocaine infusion for pain management in first-trimester abortions. Obstet Gynecol. 2006;107:269-75.

13. Wong AY, Wong K, Tang LC, Stepwise pain score analysis of the effect of local lignocaine on outpatient hysteroscopy: a randomized, double-blind, placebocontrolled trial, Fertile Steril. 2000;73(6):1234-7.

14. Alshehri AA, Alomar YM, Mohammed GA, Al-Fozan MS, Al-Harbi MS, Alrobai KA, et al. A survey on postanesthetic patient satisfaction in a university hospital. Saudi J Anaesth. 2015;9(3):303.

15. Alsaif A, Alqahtani S, Alanazi F, Alrashed F, Almutairi A. Patient satisfaction and experience with anesthesia: A multicenter survey in Saudi population. Saudi J Anaesth. 2018;12(2):304.

Cite this article as: Kanchan S, Hebbar S. Patient satisfaction and experience with various modes of Xylocaine administration for cervical dilatation and endometrial curettage: a randomized interventional study. Int J Reprod Contracept Obstet Gynecol 2020;9:1196-200. 